\title{
Understanding land use/land cover and climate change impacts on hydrological components of Usri watershed, India
}

\author{
Mukesh Kumar $^{1} \cdot$ Derrick M. Denis $^{2} \cdot$ Arnab Kundu $^{3} \cdot$ Nitin Joshi $^{4} \cdot$ Shakti Suryavanshi $^{5}$ (D)
}

Received: 16 July 2021 / Accepted: 19 November 2021 / Published online: 11 February 2022

(c) The Author(s) 2022

\begin{abstract}
Land use/cover (LULC) and climate are significant environmental factors that influence watershed hydrology across the globe. The present study attempts to understand the consequences of existing changing patterns of climate and LULC on the hydrology of the Usri watershed. Different water balance components were simulated using a semi-distributed Soil and Water Assessment Tool (SWAT) model. Sixteen scenarios were generated using combinations of four periods of climatic data (1974-84; 1985-1995; 1996-2006 and 2007-2016) and four sets of land use maps (1976; 1989; 2000 and 2014). The SWAT model performed well for monthly stream flows during calibration and validation. The study finds that the individual impact of LULC change contributes to increase in the streamflow and decrease in evapotranspiration (ET) primarily due to increase in urbanization and decrease in water bodies, forest cover and barren land of Usri watershed. The combined impact of climatic variations and land use change reveals complex interactions. The study provides insight into hydrological response to variations in climate and land use changes in Usri watershed in recent decades. The results of this study can be beneficial to the authorities, decision-makers, water resource engineers and planners for the best water resource management approaches in the perspective of climate change and LULC transformation of similar ecological regions as that of Usri.
\end{abstract}

Keywords SWAT model $\cdot$ Land use/cover $\cdot$ Climate $\cdot$ Streamflow

\section{Introduction}

Land use change and climate variability are important environmental components influencing water resource management and socioeconomic activities. They directly influence the policy framework along with planning activities required

Shakti Suryavanshi

suryavanshi.shakti@gmail.com

1 Centre for Geospatial Technologies, Sam Higginbottom University of Agriculture, Technology and Sciences, Prayagraj, Uttar Pradesh, India

2 Department of Irrigation and Drainage Engineering, Sam Higginbottom University of Agriculture, Technology and Sciences, Prayagraj, Uttar Pradesh, India

3 Department of Geo-Informatics, P.R.M.S. Mahavidyalaya, Bankura University, Bankura, West Bengal, India

4 Department of Civil Engineering, Indian Institute of Technology, Jammu, India

5 Department of Civil Engineering, Sam Higginbottom University of Agriculture, Technology and Sciences, Prayagraj, Uttar Pradesh, India for sustainable development (WMO 1966; Li et al. 2009; Wang et al. 2014a, b; Zhang et al. 2016; Yang et al. 2017; Sahoo et al. 2018). Changes in land use/land cover patterns and climate are dynamic. Prevalent process is mainly governed by natural phenomena and anthropogenic activities (Vitousek 1994; Southworth et al. 2004; Kamusoko and Aniya 2007; Xu et al. 2009; Günlü et al. 2009; Paul et al. 2017; Getachew et al. 2021). It has been observed that the changes in land use can significantly affect the streamflow, flood frequency, base flow, groundwater recharge and annual mean discharge of any watershed (Turner et al. 2001; Costa et al. 2003; Brath et al. 2006; Wang et al. 2006; Puno et al. 2019), whereas climate variability brings changes to hydrological regimes causes flow routing time, peak flows and volume (Prowse et al. 2006; Li et al. 2009; Mekonnen et al. 2018).

Quantifying the impact on the hydrologic responses of a watershed is a challenge due to its complex relationship with landscape, climate and hydrology. This makes it very important for the land use planner and water resource manager to understand and quantify these impact at a watershed scale. There are several studies that understand 
individual effect of either LULC or climate change on hydrological indicators (Ficklin et al. 2009; Wang et al. 2014a, b; Nirula et al. 2015). However, it is important to appreciate combined impact of these factors. There are few studies which understand combined impact of LULC and climate change (Mishra et al. 2009; Kim et al. 2013; Chawla and Mujumdar 2015; Yin et al. 2017).

The hydrological cycle is a system that is simple to understand, although it is difficult to quantify the processes within the system (Suryavanshi et al. 2017). Due to the complex nature of the hydrological processes, various models have been developed in the past to model the hydrological system (Arnold and Allen 1996). Models, such as the VIC model (Liang et al. 1994), Areal Non-Point Source Watershed Environment Response Simulation (ANSWERS; Beasley et al. 1977), the Stanford Watershed Model or SWM/ Hydrologic Simulation Package-Fortran IV (HSPF) (Crawford and Linsley 1966; Bicknell et al. 1997), Sacramento (Burnash et al. 1973), Agricultural Non-Point Source Pollution (AGNPS)(Young et al. 1995), Water Erosion Prediction Project (WEPP) (Laflen et al. 1991); Soil and Water Assessment Tool (SWAT) (Arnold et al. 1998) have been extensively used for water resources management. There are several studies which use hydrological models to understand the impact of LULC and climate change on hydrological variables such as streamflow groundwater recharge etc. (Mishra et al. 2009; Nie et al. 2011; Dong et al. 2014; Nirula et al. 2015; Chawla and Mujumdar 2015; Yin et al. 2017; Zhang et al. 2018). Studies of change in land use and climate at regional and local scale are best suited and furnish insight to water resources planner. Numerous studies have been conducted in perspective of hydrological variables response to LULC and climate variability in a watershed using SWAT model (Mehdi et al. 2015; El-Khoury et al. 2015; Mishra et al. 2017; Yu et al. 2018; Bal et al. 2021; Bekele et al. 2021; Chiang et al. 2021; Lopes et al. 2021; Sinha et al. 2021; Teklay et al. 2021).

In this study, a semi-distributed hydrological model, namely SWAT, has been used to monitor, model and understand the variations in LULC and climate on hydrology of the watershed. For this study, Usri, a vulnerable watershed in the India state of Jharkhand, has been selected. Owing to its vulnerability and as per Jharkhand Space Application Centre (JSAC) (2010), Usri requires urgent development and management. Hence, investigation of this watershed is very important (Kumar et al. 2018). The aim of this work is to understand the impact of changes in land use and climate on hydrological indicators such as streamflow and evapotranspiration (ET) for a period of 43 years (1974-2016). To achieve this, one factor was changed at a time, whereas other factors were kept constant. Calibrated and validated SWAT model was used to simulate combination of 4 periods of climate data and 4 land use maps, thereby generating 16 scenarios (S1, S2... S16) of varying land use and climatic conditions.

\section{Materials and methods}

\section{Study area}

Usri watershed is situated between $24^{\circ} 35^{\prime}$ and $24^{\circ} 35^{\prime} \mathrm{N}$ latitudes and $86^{\circ} 00^{\prime}$ and $24^{\circ} 35^{\prime} \mathrm{E}$ longitudes, with elevation of 210-390 $\mathrm{m}$ from the mean sea level (Fig. 1). The watershed is located in southeast part of district Giridih, Jharkhand. Climate of this area varies in seasons. December is observed to be the coldest month $\left(20^{\circ} \mathrm{C}\right)$, whereas in May month temperature peaks up to $45^{\circ} \mathrm{C}$. The study area is dominated by loamy and silty loam soil and has a subtropical climate with rainy during monsoon. Often high temperature is accompanied by high humidity levels, especially during the month of June where pre-monsoon rain occurs. The monsoon season starts from the middle of June and continues till end of September or middle of October, and maximum rainfall occurs during the month of July and August. The study area receives about $1100 \mathrm{~mm}$ of annual rainfall.

\section{Data collection and analysis}

The datasets and their sources are given in Table 1. The historic daily data of 46 years (i.e., 1971-2016) for rainfall, minimum and maximum air temperature, solar radiation, relative humidity, and sunshine hour were obtained from Ganga River Basin Management plan website (http://gisse rver.civil.iitd.ac.in/grbmp/downloaddataset.aspx).

Soil data for study area have been obtained from National Bureau of Soil Survey and Land Use Planning (NBSSLUP), Nagpur. Soils of the study area are classified as loamy $(48.55 \%)$, silty loam $(49.88 \%)$, clayey $(1.53 \%)$, silty clay loam $(0.04 \%)$. For topographical analysis of the watershed, Advanced Space-borne Thermal Emission and Reflection (ASTER) digital elevation (DEM) data were used. The monthly streamflow data at the outlet of the Usri gauging site for the period of 1985-2006 were obtained from Damodar Valley Corporation (DVC), Hazaribagh. Orthorectified Landsat satellite images for four-time period, namely October 1976, October 1989, October 2000, and September 2014, were downloaded from USGS site (http:// www.usgs.gov/in). Based upon training areas and maximum likelihood decision rule, a supervised classification of the water shed was conducted as also suggested elsewhere (Yuan et al. 2005; Paudel and Yuan 2012; Srivastava et al. 2014; Kumar et al. 2018). 


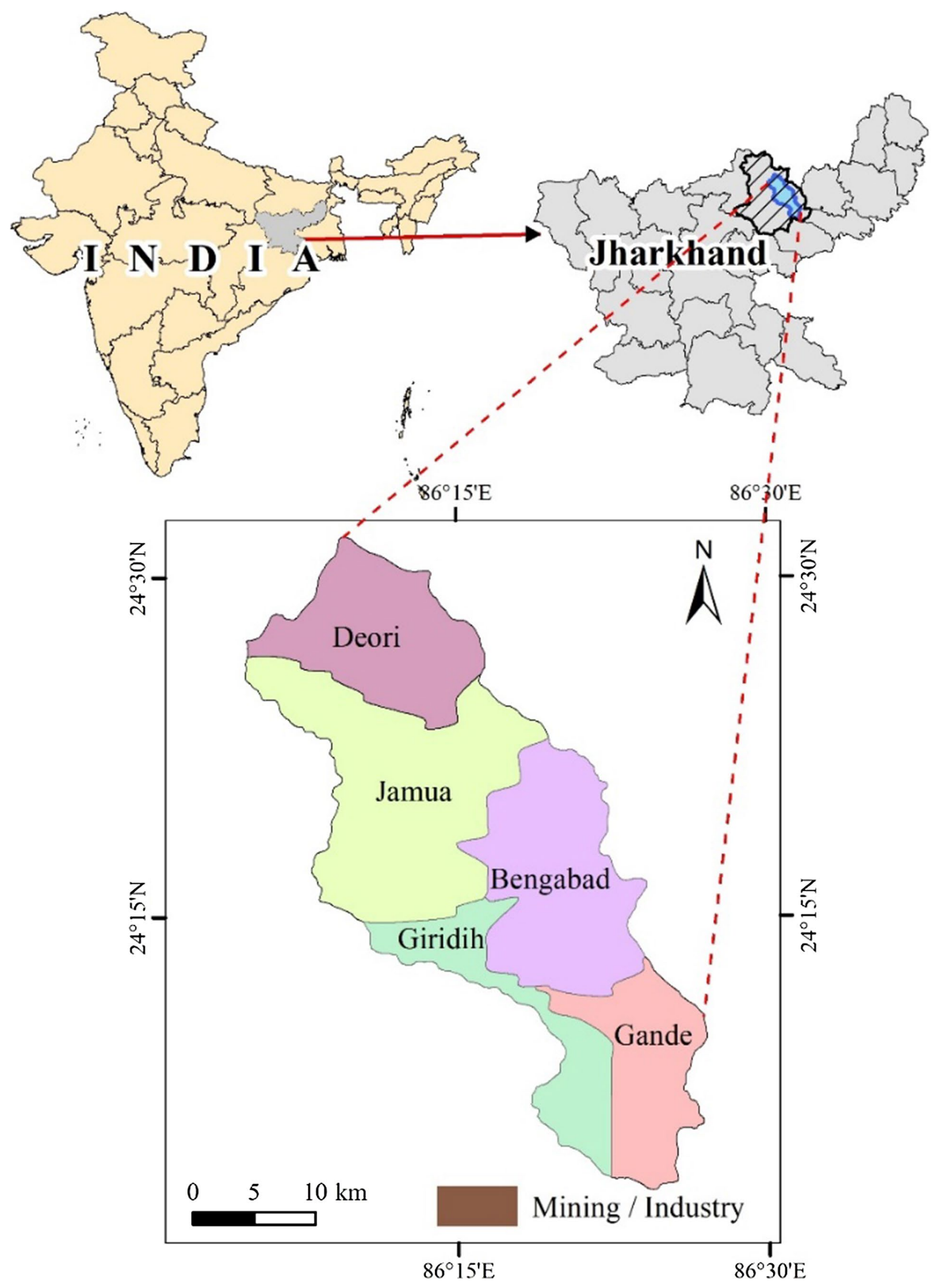

Fig. 1 Location map of study area 
Table 1 Acquired datasets and their sources

\begin{tabular}{llll}
\hline Sl. No. & Parameters & Duration & Procured from \\
\hline 1. & Metrological database & $1976-2013$ & http://gisserver.civil.iitd.ac.in/grbmp/downloaddataset.aspx \\
2. & Soil data & & National Bureau of Soil Survey and Land Use Planning, Nagpur, India \\
3. & Advanced Space-borne Thermal Emission & & htt//www.gdem.aster.ersdac.or.jp/ \\
& and Reflection (Slope, Elevation) & & \\
4. & Land Use, Land cover Map/Satellite data & 1976,1989, & www.usgs.gov.in \\
& S. & 2000, 2014 & \\
& Streamflow Data & $1985-2006$ & Damodar Valley Corporation (DVC), Hazaribagh \\
\hline
\end{tabular}

\section{SWAT model}

SWAT is a semi-distributed hydrological model that can predict the impact of anthropogenic practices on hydrological processes at different scales. Application of SWAT in runoff and sediment yield modeling (Srinivasan et al. 1993, 1998, 2010; Chaplot 2005; Setegn et al. 2008; Betrie et al. 2011; Murty et al. 2014; Suryavanshi et al. 2017; Snija et al. 2018) and climate change impact study (Wu and Johnston 2007; Ficklin et al. 2009; Moradkhani et al. 2010; Sridhar and Nayak 2010; Bae et al. 2011) has drawn noteworthy recognition over the past two decades. SWAT has also been used to understand impact of LULC and climate change (Wang et al. 2013; Zhang et al. 2013; Kim et al. 2013; EL-Khoury et al. 2015; Nirula et al. 2015; Yan et al. 2018). Water balance acts as a drive for SWAT (Neitsch et al. 2005). Water balance equation used by the SWAT is given (Eq. 1):

$\mathrm{SW}_{\mathrm{t}}=\mathrm{SW}+\sum_{t-1 .}^{t}(R-Q-\mathrm{ET}-P-\mathrm{QR})$

where $S W_{t}$ represents the final soil water content in the end of selected period ( $\mathrm{mm}), \mathrm{SW}$ is the initial soil water content $(\mathrm{mm}), t$ is the time (days), $R$ is the amount of precipitation (mm), $Q$ is the amount of surface runoff ( $\mathrm{mm})$, ET is the amount of evapotranspiration $(\mathrm{mm}), P$ is percolation $(\mathrm{mm})$, and $\mathrm{QR}$ is the amount of return flow ( $\mathrm{mm})$.

For the present study, SCS curve number method has been selected for runoff estimation. A storage routing technique combined with a crack-flow model was used to compute percolation. For estimation of ET, Hargreaves method was selected. This method provides options that give realistic results in most cases (Arnold et al. 1998; Williams et al. 2008).

\section{SWAT model setup for the Usri watershed}

The SWAT model setup was performed with the interface of ArcSWAT 2009.93.7 within ArcGIS software. Stream networks, delineation of catchment boundary from the DEM and further subdivision of the catchment into sub basins were done using this interface. Based on the unique combination of soil, land use and slope, the sub-basins are further subdivided into Hydrological Response Units (HRUs). Total of 5 sub-watersheds and 180 HRUs are generated in the process. The weather data are integrated into the model along with the flow data in order to run the simulations. Monthly calibrations were performed using manual adjustment of input parameters to achieve acceptable agreement between synthetic and observed streamflow. Simulation reliability was examined using a validation process. Finally, the calibrated model is utilized to describe conclusions about the spatial aspects of the hydrological processes of Usri watershed.

\section{Criteria for model evaluation}

Different types of statistics provide useful numerical measures of the degree of agreement between model simulated and recorded quantities (Chaube et al. 2011; Murty et al. 2014). In this study, statistical criteria such as coefficient of determination, $R^{2}$ (Willmott 1981; Leagates and McCabe 1999 ) and the Nash-Sutcliffe efficiency coefficient, $E_{\mathrm{NS}}$ (Nash and Sutcliffe 1970) were used to evaluate model performance as given by Eqs. 2-3, respectively, where $Y_{i}^{\text {obs }}$ is the $i$ th observed data, $Y_{\text {mean }}{ }^{\text {obs }}$ is the mean of observed data, $Y_{i}^{\text {sim }}$ is the $i$ th simulated value, and $Y_{\text {mean }}{ }^{\text {sim }}$ is the mean model simulated value (Eqs. 2 and 3):

$R^{2}=\left(\frac{\sum_{i=0}^{n}\left(Y_{i}^{\text {obs }}-Y_{\text {mean }}^{\text {obs }}\right)\left(Y_{i}^{\text {sim }}-Y_{\text {mean }}^{\text {sim }}\right)}{\sqrt{\sum_{i=1}^{n}\left(Y_{i}^{\text {obs }}-Y_{\text {mean }}^{\text {obs }}\right)^{2} \sqrt{\sum_{i=1}^{n}\left(Y_{i}^{\text {sim }}-Y_{\text {mean }}^{\text {sim }}\right)^{2}}}}\right)^{2}$

$E_{N S}=1-\left[\frac{\sum_{i=1}^{n}\left(Y_{i}^{o b s}-Y_{i}^{s i m}\right)^{2}}{\sum_{i=1}^{n}\left(Y_{i}^{o b s}-Y_{\text {mean }}^{o b s}\right)^{2}}\right]$ 


\section{Evaluation of impact of LULC and climate change}

To assess the outcome of change in LULC and climate upon the hydrological response of Usri watershed, one-factor-at-atime approach as suggested by Li et al. (2009) was utilized. Climatic datasets for the period of 1974-2016 were broken into four periods, i.e., 1974-1984, 1985-1995, 1996-2006 and 2007-2016, and LULC maps for the year 1976, 1989, 2000 and 2014 were used in this study (Fig. 2). By using these datasets, sixteen scenarios were designed, which are shown in Table 2. These scenarios will provide deeper insight into the impacts of land cover and climate change within the Usri watershed.

If the LULC map and meteorological datasets were of almost same time period, then it is termed as a real or baseline scenario and if the LULC and meteorological datasets are of different time periods, then it is termed as a hypothetical scenario. The difference between hydrological variables (streamflow and ET) for real and hypothetical scenarios will give the isolated and combined impact of climate and LULC change. For example, in scenario S1, the LULC of 1976 and climate data of 1974-84 period was used and therefore it is termed as a real or baseline scenario. In scenario S2, the LULC of 1989 and climate data of 1974-84 was used and therefore it is termed as a hypothetical scenario. The difference between streamflow obtained from scenario S2 and S1 would give the isolated impact of LULC during 1976-89 period. In scenario S5, LULC of 1976 and climate of 1985-95 was used and difference between streamflow
Table 2 Different scenario for assessing hydrological impacts of land use and climatic variability during 1974-2016

\begin{tabular}{lll}
\hline $\begin{array}{l}\text { Scenarios consid- } \\
\text { ered }\end{array}$ & Land use & $\begin{array}{l}\text { Timeline of considered } \\
\text { climatic conditions (Temp., } \\
\text { Rainfall.) }\end{array}$ \\
\hline S1 & 1976 & $1974-1984$ \\
S2 & 1989 & $1974-1984$ \\
S3 & 2000 & $1974-1984$ \\
S4 & 2014 & $1974-1984$ \\
S5 & 1976 & $1985-1995$ \\
S6 & 1989 & $1985-1995$ \\
S7 & 2000 & $1985-1995$ \\
S8 & 2014 & $1985-1995$ \\
S9 & 1976 & $1996-2006$ \\
S10 & 1989 & $1996-2006$ \\
S11 & 2000 & $1996-2006$ \\
S12 & 2014 & $1996-2006$ \\
S13 & 1976 & $2007-2016$ \\
S14 & 1989 & $2007-2016$ \\
S15 & 2000 & $2007-2016$ \\
S16 & 2014 & $2007-2016$ \\
\hline
\end{tabular}

obtained by S5 and S1 would give the effect of climate change during 1974-95.

In scenario S6, LULC of 1989 and climate data of 1985-95 was used. The difference between streamflow obtained from S6 and S1 will give the combined effect of LULC and climate change during 1974-95 period. The percentage change in (a)
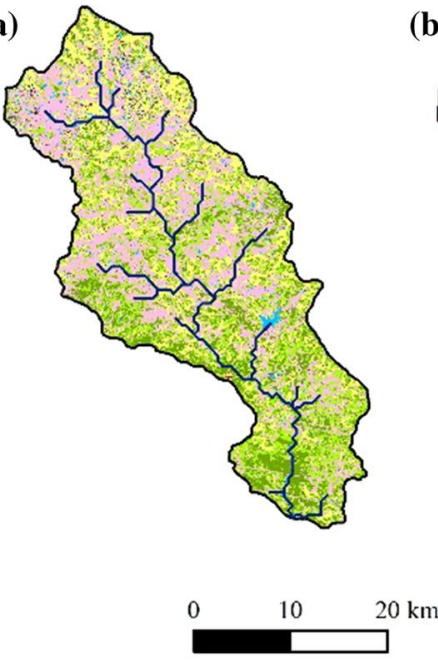

(b)

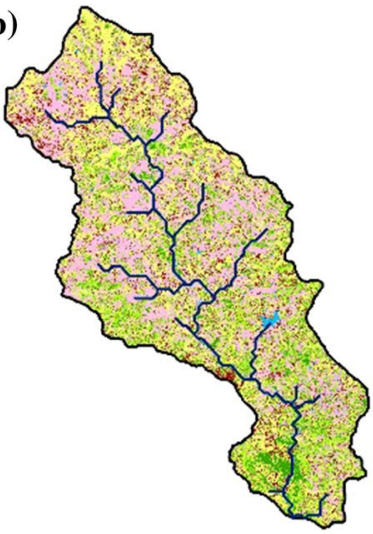

(c)

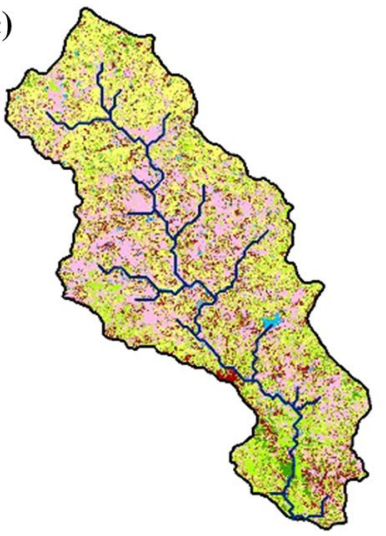

(d)

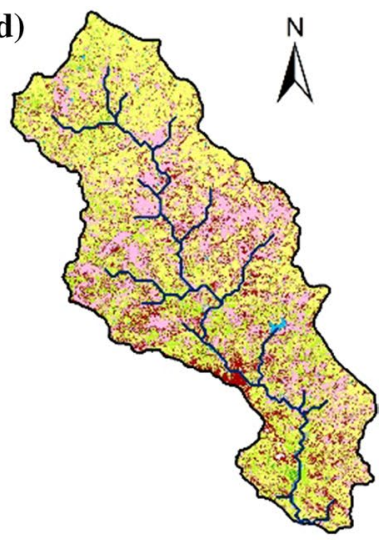

\section{LULC}

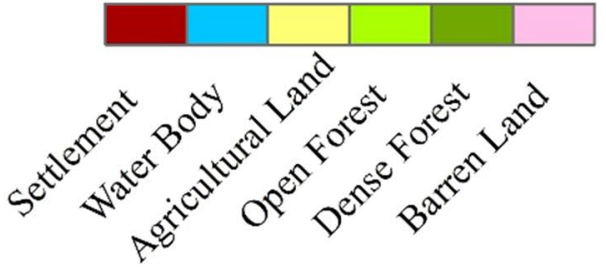

Drainage

Fig. 2 Land use/land cover maps of study area: a 1976; b 1989; c 2000; d 2014 (Modified after Kumar et al. 2018) 
streamflow is due to individual LULC, climate and combined LULC and climate given by Eqs. 4a-c, respectively.

$\Delta S R_{\mathrm{LULC}}^{1985-95}=\left(\frac{S 2-S 1}{S 1}\right) \times 100$

$\Delta S R_{\text {climate }}^{1985-95}=\left(\frac{S 5-S 1}{S 1}\right) \times 100$

$\Delta S R_{\text {combined }}^{1985-95}=\left(\frac{S 6-S 1}{S 1}\right) \times 100$

Similar analogy is adopted for studying the individual and combined impact of LULC and climate parameters on streamflow and ET for other time periods (i.e., 1996-2006 and 2007-2016).

\section{Results and discussion}

\section{Evolution of the SWAT model for Usri Watershed}

This procedure includes calibration and validation of SWAT model. Manual calibration has been adopted for this study. Before starting to calibrate, few important observations of the model developer and users of the model were studied; this helped in deciding the parameters to be adjusted. The parameters such as threshold depth of water in the shallow

Table 3 Initial and calibrated parameter values

\begin{tabular}{llll}
\hline S1. No. & Parameter & Default value & Values after calibration \\
\hline 1 & Revapmn & 10.0 & 11.5 \\
2 & CH_N & 0.014 & 0.10 \\
3 & Cn2 & Varies & $5 \%$ increase \\
4 & EPCO & 1 & 0.01 \\
5 & Soil_Awc & $0-1$ & 0.5 \\
\hline
\end{tabular}

aquifer for percolation to occur (REVAPMN), Manning coefficient for main channel $\left(\mathrm{CH}_{-} \mathrm{N}_{2}\right)$, SCS runoff Curve Number for moisture condition II $\left(\mathrm{CN}_{2}\right)$, plant evaporation compensation factor (EPCO) and available water capacity of the soil layer (Soil_Awc) were used for model calibration. Value between lower and upper limits has been taken to perform the model. The default model value and calibrated values used in the SWAT model are presented in Table 3.

For calibration, observed monthly streamflow at Usri gauging site was equated with the model simulated stream flow as shown in Figs. 4 and 5. For calibration purpose, model run was performed between years 1985-1995 (11 years) with land use of year 1989. It is evident from Fig. 3 that the peak values of the simulated monthly streamflow closely match with observed one but at different magnitude. It is noticed from Fig. 4 that the simulated streamflow values are dispersed uniformly about the 1:1 line for lower values of observed streamflow; however, the model slightly under-predicts the high values of discharge. A satisfactory value of $R^{2}$, i.e., 0.87 , and $\mathrm{E}_{\mathrm{NS}}$ model efficiency, i.e., 0.76 , indicate a familiarity between the observed and simulated streamflow as shown in Table 4. The result obtained from SWAT model gives the satisfactory result of monthly discharge of the watershed which allows for the further investigation.

For further utilization of the model, the calibrated model evaluated against a different set of measured streamflow during 1996-2006 (11 years) with land use of year 2000 at Usri site. The observed monthly streamflow and simulated monthly streamflow of Usri site for the validation period were compared as shown in Figs. 5 and 6. Simulated monthly streamflow and observed monthly streamflow show a good consensus of Usri watershed site which is shown in Fig. 4. The simulated peaks are, however, marginally under-predicted from the measured spikes for the months of Aug-Sept 1996, Aug 1998, Sept 2000, Sept 2001, Sept 2002, July 2004 and Sept 2006. It is evident (Fig. 6) that most of the compared points are uniformly distributed for
Fig. 3 Observed and simulated streamflow (calibrated) for June 1985-1995

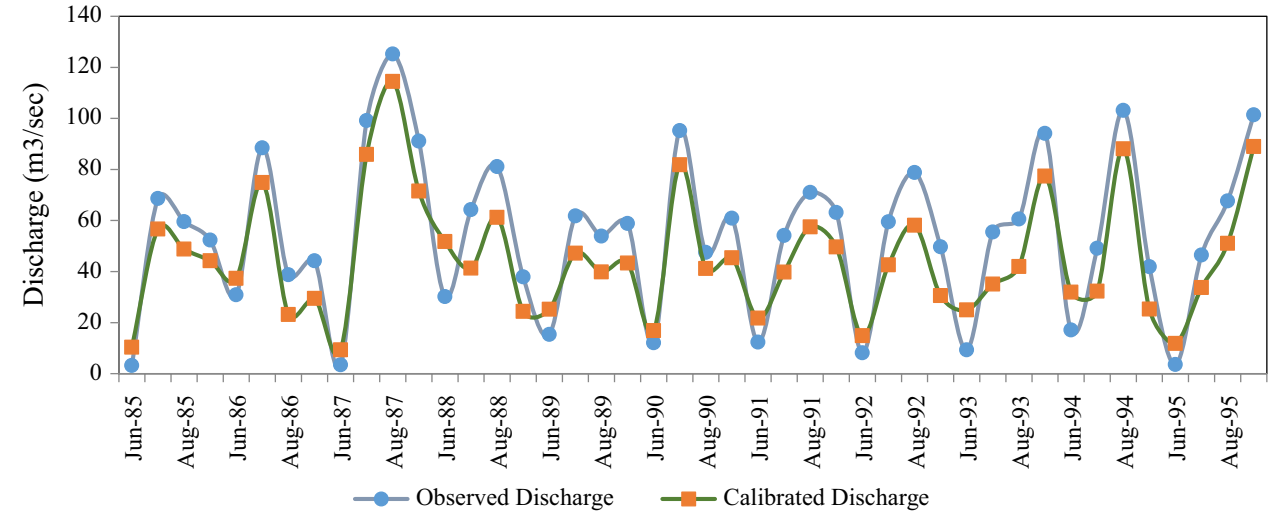


Fig. 4 Comparison between the observed and simulated streamflow for the years 1985-1995 for model calibration

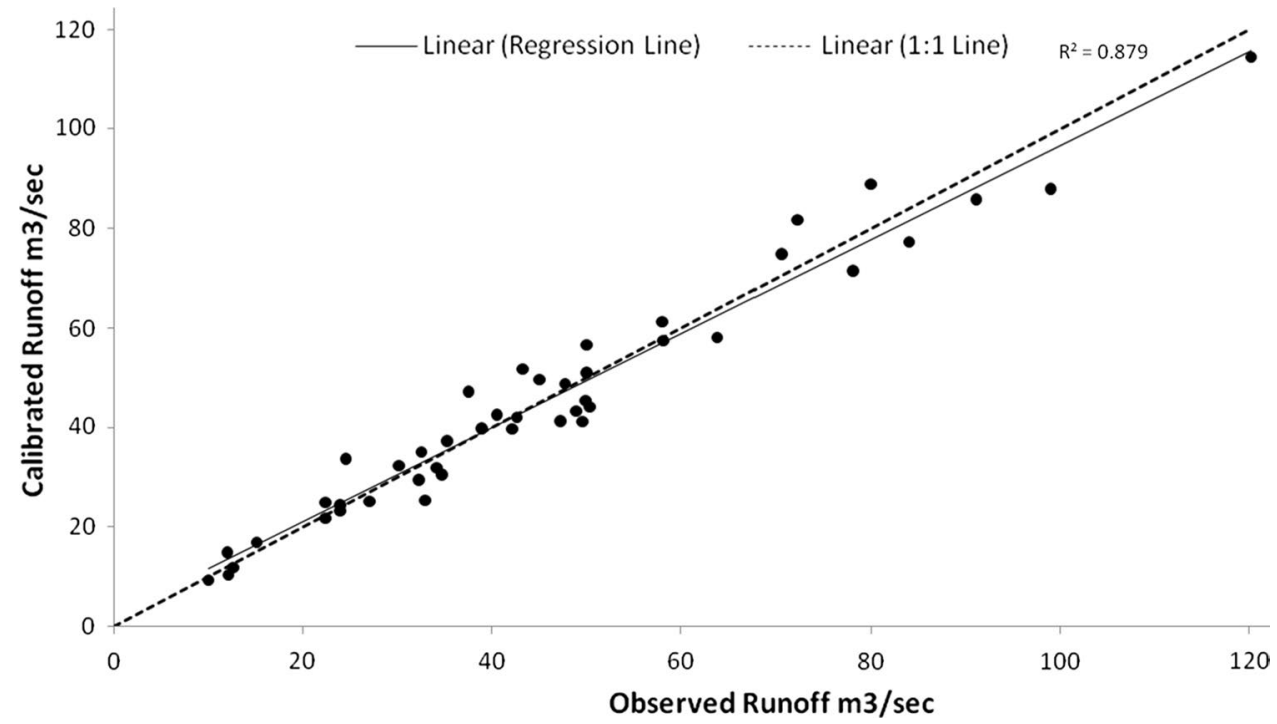

Table 4 Statistical analysis of observed and simulated monthly streamflows during calibration (1985-1995) and validation (19962006) process

\begin{tabular}{|c|c|c|c|c|}
\hline \multirow[t]{2}{*}{ Statistical parameters } & \multicolumn{2}{|c|}{$\begin{array}{l}\text { Streamflow }\left(\mathrm{m}^{3} / \mathrm{sec}\right) \\
\text { during calibration } \\
(1985-1995)\end{array}$} & \multicolumn{2}{|c|}{$\begin{array}{l}\text { Streamflow }\left(\mathrm{m}^{3} / \mathrm{sec}\right) \\
\text { during validation } \\
(1996-2006)\end{array}$} \\
\hline & Observed & Simulated & Observed & Simulatec \\
\hline Mean & 53.88 & 45.07 & 48.15 & 45.57 \\
\hline Maximum & 122.2 & 114.5 & 96.15 & 89.57 \\
\hline Count & 44 & 44 & 44 & 44 \\
\hline $\begin{array}{l}\text { Coefficient of determi- } \\
\text { nation }\end{array}$ & 0.87 & & 0.83 & \\
\hline $\begin{array}{l}\text { Nash-Sutcliffe effi- } \\
\text { ciency }\end{array}$ & 0.76 & & 0.82 & \\
\hline
\end{tabular}

lower discharge, but for the higher values of discharge, the simulated values are slightly below 1:1 line.

Table 4 shows the statistics for all the year of streamflow. It has been observed that coefficient of determination and Nash-Sutcliffe model efficiency was found to be close ( 0.83 and 0.82) for the year 1996-2006. For the model validation, the coefficient of determination $\left(R^{2}\right)$ and Nash-Sutcliffe model efficiency $\left(\mathrm{E}_{\mathrm{NS}}\right)$ were found to be 0.83 and 0.82 , respectively, which reflect a close agreement between the simulated monthly streamflow and observed monthly streamflow for the years 1996-2006. The calibration and validation results indicate good streamflow simulations as per the model evaluation guidelines given by Moriasi et al. (2007). Hence, results indicate overall prediction of monthly

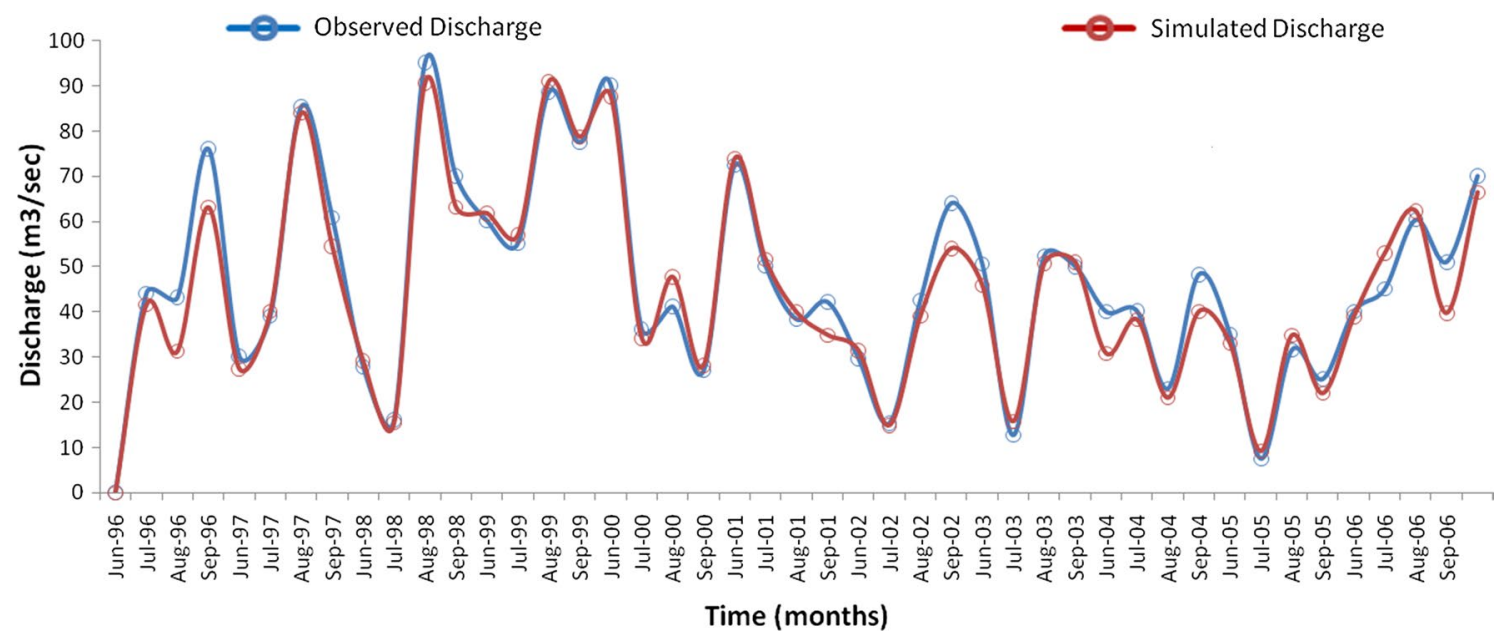

Fig. 5 Observed and simulated streamflow for 1996-2006 for model validation 
Fig. 6 Comparison between the observed streamflow and simulated streamflow of 1996-2006 for model validation at Usri
Table 5 Average annual hydrological components in different land use classes with climatic condition $(\mathrm{C} 1)$

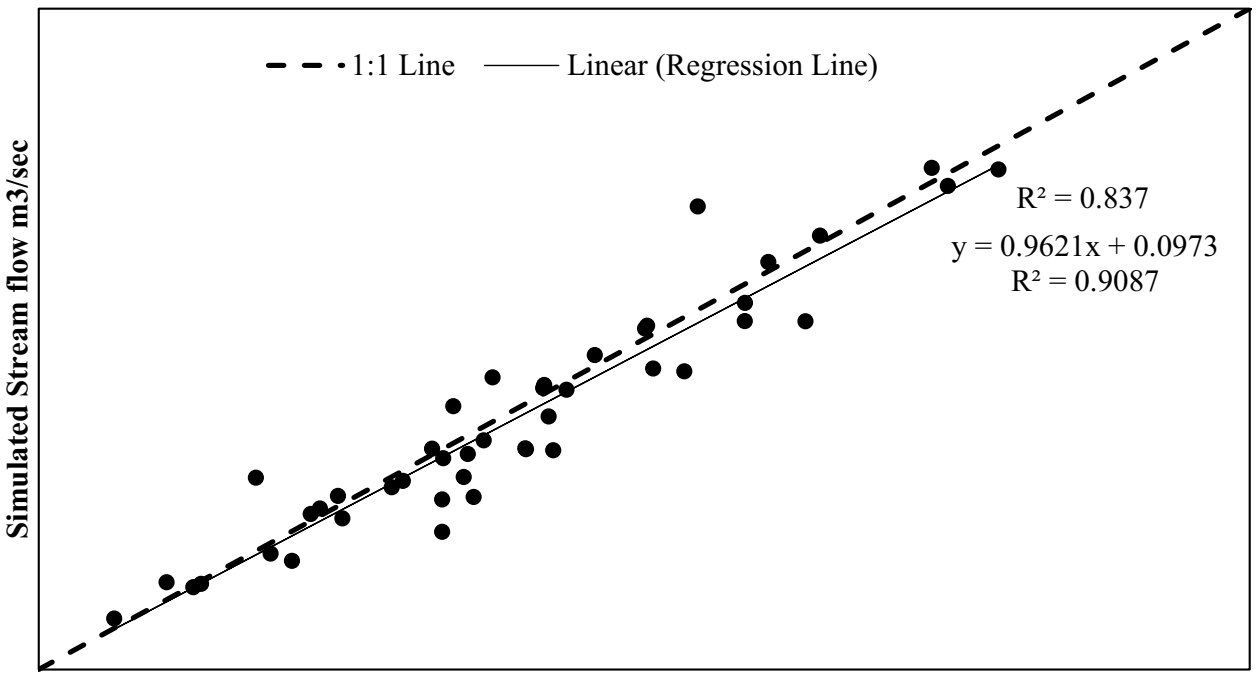

Observed Runoff m3/sec

\begin{tabular}{lllllll}
\hline Scenarios & Land use & Climate (C1) & $\begin{array}{l}\text { Precipita- } \\
\text { tion (mm/ } \\
\text { year) }\end{array}$ & $\begin{array}{l}\text { Stream- } \\
\text { flow (mm/ } \\
\text { year) }\end{array}$ & $\begin{array}{l}\text { Groundwater contribu- } \\
\text { tion to streamflow (mm/ } \\
\text { year) }\end{array}$ & ET (mm/year) \\
\hline S1 & 1976 & $1974-1984$ & 975.8 & 500.63 & 106.38 & 375.4 \\
S2 & 1989 & $1974-1984$ & 975.8 & 519.68 & 99.65 & 358.8 \\
S3 & 2000 & $1974-1984$ & 975.8 & 662.53 & 12.55 & 311.2 \\
S4 & 2014 & $1974-1984$ & 975.8 & 668.78 & 10.52 & 307.2 \\
\hline
\end{tabular}

\begin{tabular}{lllllll}
\hline Scenarios & Land use & Climate (C2) & $\begin{array}{l}\text { Precipita- } \\
\text { tion (mm/ } \\
\text { year) }\end{array}$ & $\begin{array}{l}\text { Stream- } \\
\text { flow }(\mathrm{mm} / \\
\text { year) }\end{array}$ & $\begin{array}{l}\text { Groundwater contribu- } \\
\text { tion to streamflow (mm/ } \\
\text { year) }\end{array}$ & ET (mm/year) \\
\hline S5 & 1976 & $1985-1995$ & 1083.4 & 574.43 & 117.58 & 391.8 \\
S6 & 1989 & $1985-1995$ & 1083.4 & 595.3 & 110.12 & 376.3 \\
S7 & 2000 & $1985-1995$ & 1083.4 & 746.93 & 12.34 & 331.8 \\
S8 & 2014 & $1985-1995$ & 1083.4 & 753.00 & 11.01 & 328.2 \\
\hline
\end{tabular}

\begin{tabular}{|c|c|c|c|c|c|c|}
\hline Scenarios & Land use & Climate (C3) & $\begin{array}{l}\text { Precipita- } \\
\text { tion }(\mathrm{mm} / \\
\text { year) }\end{array}$ & $\begin{array}{l}\text { Streamflow } \\
\text { (mm/year) }\end{array}$ & $\begin{array}{l}\text { Groundwater contribution } \\
\text { to streamflow (mm/year) }\end{array}$ & ET (mm/year) \\
\hline S9 & 1976 & 1996-2006 & 944.9 & 490.89 & 103.67 & 357.9 \\
\hline S10 & 1989 & 1996-2006 & 944.9 & 508.18 & 96.09 & 344 \\
\hline S11 & 2000 & 1996-2006 & 944.9 & 637.54 & 11.01 & 308.6 \\
\hline $\mathrm{S} 12$ & 2014 & 1996-2006 & 944.9 & 642.25 & 8.97 & 306.1 \\
\hline
\end{tabular}

Table 7 Average annual hydrological components in different land use classes with climatic condition (C3)
Table 6 Average annual hydrological components in different land use classes with climatic condition $(\mathrm{C} 2)$ streamflow by the SWAT during the calibration and validation period was satisfactory and therefore accepted for further analysis.

\section{Impact of LULC and climatic variability on hydrology under a hypothetical scenario}

In order to assess the impact on hydrology due to land use and climatic factors, different land uses are compared with 
Table 8 Average annual hydrological components in different land use classes with climatic condition (C4)

\begin{tabular}{lllllll}
\hline Scenarios & Land use & Climate (C4) & $\begin{array}{l}\text { Precipita- } \\
\text { tion (mm/ } \\
\text { year) }\end{array}$ & $\begin{array}{l}\text { Streamflow } \\
\text { (mm/year) }\end{array}$ & $\begin{array}{l}\text { Groundwater contribution } \\
\text { to streamflow (mm/year) }\end{array}$ & ET (mm/year) \\
\hline S13 & 1976 & $2007-2016$ & 1109 & 643.17 & 111.27 & 355.6 \\
S14 & 1989 & $2007-2016$ & 1109 & 665 & 105.25 & 337 \\
S15 & 2000 & $2007-2016$ & 1109 & 808.27 & 13 & 294.7 \\
S16 & 2014 & $2007-2016$ & 1109 & 814 & 10.87 & 291.3 \\
\hline
\end{tabular}

the different climatic conditions. Rainfall with hydrological components such as streamflow, groundwater contribution to streamflow (GwQ) and evapotranspiration (ET) simulated by SWAT with different land use patterns and climatic conditions is presented in Tables 5, 6, 7 and 8. Table 5 shows the different hypothetical scenarios S1, S2, S3, and S4 implying the sole effects of land use change with climatic condition of 1974-1984. Similarly, Tables 6, 7 and 8 exhibit the hypothetical scenarios S5, S6, S7 and S8 with climatic condition of 1985-1995; hypothetical scenarios S9, S10, S11 and S12 with climatic condition of 1996-2006 and hypothetical scenarios S13, S14, S15 and S16 with climatic condition of 2007-2016.

By comparing the baseline scenario (Table 5) S1 (land use, 1976; climatic condition 1974-1984) with S2, S3 and $\mathrm{S} 4$, it was found that there is an increase of streamflow (19.05 mm, $161.90 \mathrm{~mm}$ and $168.15 \mathrm{~mm}$ in 1989, 2000 and 2014, respectively) in S2, S3 and S4 scenarios. However, a decline in GwQ $(-6.73 \mathrm{~mm},-93.83 \mathrm{~mm}$ and $-95.86 \mathrm{~mm})$ and ET $(-16.60 \mathrm{~mm},-64.20 \mathrm{~mm}$ and $-68.20 \mathrm{~mm})$ was found. Similar results (increase in streamflow and decrease in GwQ and ET) can be observed in different hypothetical scenarios of S5-S16 although with different magnitudes (Tables 6, 7, 8).

Kumar et al. (2018) conducted a study on land use change in Usri watershed for years 1976, 1989, 2000 and 2014. The results obtained from the study concluded that there was an increase of settlement (3\% in 1976 to $17 \%$ in 2014) and agriculture (25\% in 1976 to $41 \%$ in 2014). That study also reveals that a decline in total forest cover (dense and open forest) (28.75\% in 1976 to $14.89 \%$ in 2014) and barren land (36\% in 1976 to $24 \%$ in 2014). The changes in land use pattern (as suggested by Kumar et. al. 2018) may be a reason for increasing streamflow and decreasing GwQ and ET. The results infer the sole effect of land use change between the given hypothetical scenarios in Usri watershed.

In this study, the influence of climatic variability upon the hydrology of Usri watershed has been assessed. In order to do so, comparisons were made using the hypothetical scenarios (S1, S5, S9 and S13), where similar land use (1976) was compared with different climatic conditions (1974-84, 1985-95, 1996-2006, 2007-16) (Tables 5, 6, 7, 8). Result exhibits that increase in precipitation by $107.6 \mathrm{~mm}$ (with scenario S1 and S5) causes increase in streamflow by $73.80 \mathrm{~mm}$, whereas decrease in precipitation by $138.5 \mathrm{~mm}$ (with scenario S5 and S9) causes decrease in streamflow by $83.54 \mathrm{~mm}$. Similarly, increase in precipitation by $164.1 \mathrm{~mm}$ causes increase in streamflow by $152.28 \mathrm{~mm}$ (scenario $\mathrm{S} 9$ and S13). The obvious distinctions between $\mathrm{S} 1, \mathrm{~S} 5, \mathrm{~S} 9$, and $\mathrm{S} 13$ indicate the effects solely originate by climate variability. Repeated trial (scenarios S2, S6, S10 and S14; S3, S7, S11 and S15; S4, S8, S12, S16) (Tables 5, 6, 7, 8) also shows that increase in rainfall causes increase in streamflow and decrease in rainfall causes decrease in streamflow. The findings of hypothetical scenarios explain that both LULC and climatic variability have a noteworthy and intermingled effect on the hydrology of Usri watershed.

\section{Impact of LULC and climatic variability on hydrology under real scenario}

In order to understand the hydrology of Usri watershed, the real scenario is presented where land use and climatic variability changes simultaneously. The climatic conditions of 1974-1984 were chosen with land use of 1976 (S1); climatic conditions of 1985-1995 were chosen with land use of 1989 (S6); climatic conditions of 1996-2006 were chosen with land use of 2000 (S11) and climatic conditions of 2007-2016 were chosen with land use of 2014 (S16) (Tables 5, 6, 7, 8). The result exhibits that increase in precipitation ( $\mathrm{S} 1$ with $\mathrm{S} 6$ ) and change in land use causes increase in streamflow by $94.67 \mathrm{~mm}$, increase in GwQ by $3.74 \mathrm{~mm}$ and ET by $3.74 \mathrm{~mm}$. However, change in land use and decrease in precipitation (S6, S11) also tend to increase in streamflow by $42.24 \mathrm{~mm}$, decrease in GwQ by $99.11 \mathrm{~mm}$ and decrease in ET by $67.7 \mathrm{~mm}$ indicate that combined effect of land use and precipitation play an important role. Again increase in precipitation with different land use (S11, S16) causes increase in streamflow by 176.46 , decrease in GwQ by 0.14 and decrease in ET by $17.3 \mathrm{~mm}$. 


\section{Discussions}

\section{Isolated impact of LULC on streamflow and ET}

LULC contributes to increase in the streamflow during all the three periods analyzed. During 1985-1995, 1996-2006 and 2006-16, the streamflow increased by $3.8 \%, 25.4 \%$ and $0.7 \%$, respectively (Fig. 7a, b). The increase in streamflow is primarily due to urbanization, which results in reducing infiltration, thus increasing the surface runoff. During 1974-2014, the settlement area increased by $398 \%$ resulting in greater streamflow. The maximum increase in streamflow was observed during 1996-2006 period. During that period, the percentage area under settlement increased from $8 \%$ in 1989 to $13.5 \%$ in 2000 . During 2006-2016 period, the percentage area under settlement further increased to $16.8 \%$ resulting in an increase in streamflow. Urbanization leads to increase in impervious areas, resulting in a decreased soil infiltration. With the reduction in base flow contribution to stream flow, the surface runoff increases, which proceeds in more recurrent and severe flooding (Rose and Peters 2001; Kim et al. 2002; Huang et al. 2008; Wang et al. 2014a, b). The increase in streamflow is also attributed to decrease in water bodies and forest cover.
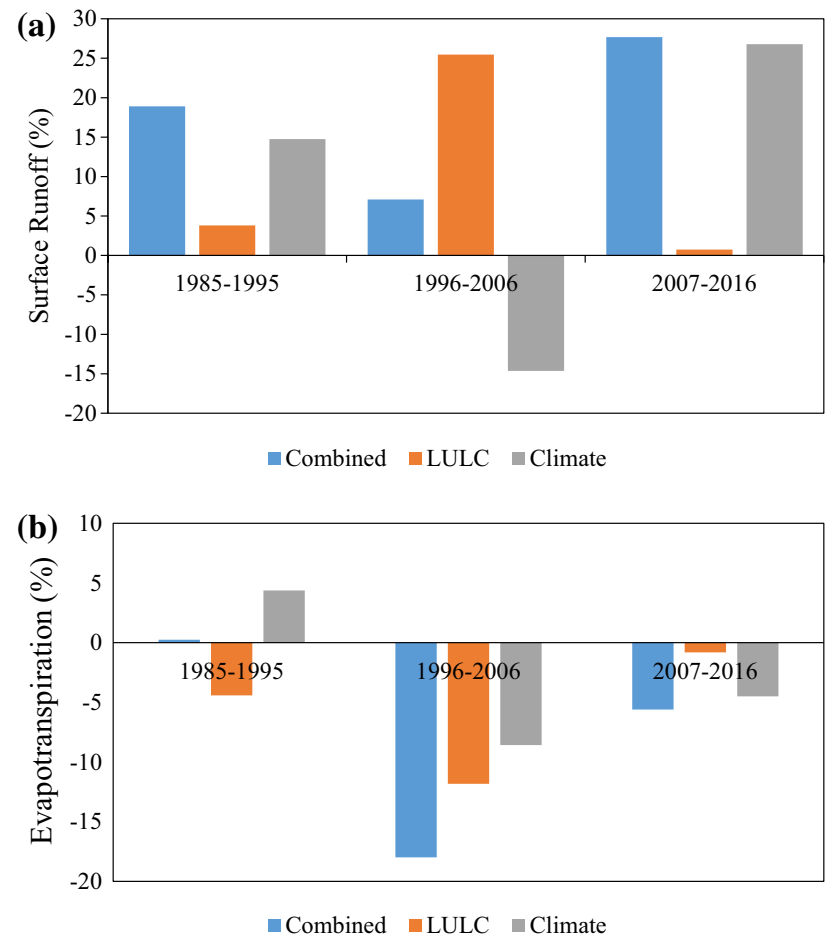

Fig. 7 a Individual and combined impact of LULC and climate on surface runoff; $\mathbf{b}$ individual and combined Impact of LULC and climate on ET
LULC results in decrease in ET during all the three periods analyzed. During 1985-1995, 1996-2006 and 2006-16, the ET decreased by $4.4 \%, 11.8 \%$ and $0.8 \%$, respectively. Decrease in ET is primarily due to decrease in forest cover, water bodies and barren land. The forest cover, water bodies and barren land during 1974-2014 period were reduced by $92 \%, 54 \%$ and 30\%, respectively. During 1976, the percentage area under forest cover was $28 \%$ which reduced to $23.7 \%$ in 1989 and further reduced to $19.4 \%$ and $2 \%$ during 2000 and 2014, respectively. The percentage area under water bodies also reduced from 6\% in 1976 to $5.1 \%$ in 1989 and further reduced to 3.5 and $2.7 \%$ during 2000 and 2014, respectively. Similarly, the percentage area under barren land was 36\% in 1976, which reduced to 34\% in 1989 and further reduced to $30 \%$ and $24 \%$ during 2000 and 2014, respectively. The percentage area under agriculture increased from $25 \%$ in in 1976 to $28.5 \%$ in 1989 and further increased to $33 \%$ and $40 \%$ during 2000 and 2014, respectively. Liu et al. (2003) reported that the forest area contributes to the largest fraction of the total ET. During 1974-2014 period, agriculture area also increased by $22 \%$, but its contribution to total ET was less as compared to that of forest land (Liu et al. 2003).

\section{Isolated impact of climate variability on streamflow and ET}

Climate variability contributes to the increase in the streamflow during 1985-1995 and 2007-16 period, whereas streamflow decrease during 1996-2006 (Fig. 7a). During 1985-1995 and 2006-16, the streamflow increased by $14.7 \%$, and $26.7 \%$, respectively, and during 1996-2006, it decreases by $14.6 \%$. The average precipitation increased from $975.8 \mathrm{~mm}$ during $1974-84$ period to $1083.4 \mathrm{~mm}$ in 1985-1995 period, which resulted in an increase in streamflow. During 1996-2006, the average precipitation reduced to $945 \mathrm{~mm}$ which results in a decrease in streamflow. During 2007-16 period, average precipitation increased from 945 to $1109 \mathrm{~mm}$; this also resulted in increase of streamflow.

Climate variability results in increase in ET during 1985-1995 period, and it decreases in 1996-2006 and 2007-16 period (Fig. 7b). During 1985-1995, ET increased by $4.3 \%$ and during $1996-2006$ and $2007-16$ period it decreased by $8.5 \%$ and $4.5 \%$, respectively.

\section{Combined impacts of LULC and climate changes on streamflow and ET}

Combined effect of LULC and climate change showed an increase in the streamflow during all the three period analyzed (Fig. 7a, b). During 1985-1995, 1996-2006 and $2006-16$, the streamflow increased by $18.9 \%, 7 \%$ and $27.6 \%$, respectively. The percentage area under settlement increased during all the three periods considered. During 


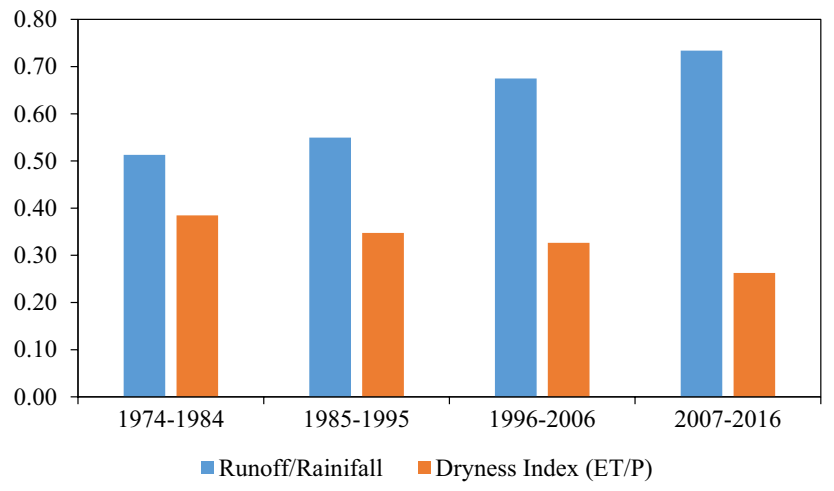

Fig. 8 Runoff-to-rainfall ratio (RR) and dryness index (ET/P) during 1974-2016

1985-1995 and 2006-16 periods, there was a greater percentage increase in streamflow as compared to 1996-2006. This is primarily due to combined effect of increase in precipitation and urbanization. In spite of reduced precipitation during the period from 1996-2006, the increase in streamflow was observed, primarily due to LULC change. Combined effect of LULC and climate change results in a marginal increase in ET during 1985-1995 periods, and then, it decreases during 1996-2006 and 2007-16 period. During 1985-1995, there was an increase of $0.24 \%$ and during 1996-2006 and 2007-16 ET decreased by $18 \%$ and $5.6 \%$, respectively.

Runoff-to-rainfall ratio (RR) and dryness index (ET/P) were also computed for the four baseline scenarios ( $\mathrm{S}$, S6, S11 and S16), and it was found that LULC and climate variability contribute to an increase in runoff-to-rainfall ratio and decrease in dryness index (Fig. 8).

Compared to 1974-84 period, the RR increased by 43\% during 2007-16 period and dryness index reduced by $31.7 \%$. There was an increase in precipitation and runoff by $13 \%$ and $62.6 \%$, respectively, and decrease in ET by $22.4 \%$ during $1974-84$ to $2007-16$ period.

Common to many Indian watersheds, Usri is exposed to the pressure of developing urban and rural population and climate-related hazards. Consequently, appropriate management decisions and actions by the government unit focusing on the restoration of natural resources have to be given into consideration.

\section{Conclusions}

This research investigates the individual and combined impact of land use change and climatic variations in Usri watershed implying a semi-distributed SWAT model. The results affirm that: (a) SWAT is an accurate model for diagnosis of the Usri watershed and can be further utilized for analysis.

(b) Isolated impact of LULC on streamflow and ET reveals that due to increase in urbanization and decrease in water bodies, forest cover and barren land (LULC change), there are an increase in streamflow and decrease in ET in Usri watershed.

(c) The isolated impact of climate variability also reveals the same trend of streamflow and ET, although with different magnitudes.

(d) The combined impacts of LULC and climate variability on streamflow and ET reveal an intricate relation between land use change and climate variability in the Usri watershed.

Acknowledgements The authors are thankful to the Damodar Valley Corporation (DVC), Hazaribagh, for providing observed streamflow data and the National Bureau of Soil Survey and Land use planning (NBSSLUP) for soil data.

Funding The author(s) received no specific funding for this work.

Availability of data and material Some or all data, models that support the findings of this study are available from the corresponding author upon reasonable request.

Code availability It is available on request.

\section{Declarations}

Conflict of interest The authors declare no conflict of interest.

Ethical approval Not applicable.

Consent to participate Not applicable.

Consent for publication This work is not published elsewhere.

Open Access This article is licensed under a Creative Commons Attribution 4.0 International License, which permits use, sharing, adaptation, distribution and reproduction in any medium or format, as long as you give appropriate credit to the original author(s) and the source, provide a link to the Creative Commons licence, and indicate if changes were made. The images or other third party material in this article are included in the article's Creative Commons licence, unless indicated otherwise in a credit line to the material. If material is not included in the article's Creative Commons licence and your intended use is not permitted by statutory regulation or exceeds the permitted use, you will need to obtain permission directly from the copyright holder. To view a copy of this licence, visit http://creativecommons.org/licenses/by/4.0/.

\section{References}

Arnold JG, Allen PM (1996) Estimating hydrologic budgets for three Illinois watersheds. J Hydrol 176(1-4):57-77 
Arnold JG, Srinivasan R, Muttiah RS, Williams JR (1998) Large area hydrologic modeling and assessment part I: model development 1. J Am Water Resour Assoc 34(1):73-89

Bae DH, Jung IW, Lettenmaier DP (2011) Hydrological uncertainties in the climate change from IPCC AR4 GCM simulations of Chungju Basin Korea. J Hydrol 401:90-105

Bal M, Dandpat AK, Naik B (2021) Hydrological modeling with respect to impact of land-use and land-cover change on the runoff dynamics in Budhabalanga river basing using ArcGIS and SWAT model. Remote Sens Appl Soc Environ 23:100527. https://doi.org/ 10.1016/j.rsase.2021.100527

Beasley DB, Monke EJ, Huggins LF (1977) ANSWERS: A model for watershed planning, Purdue Agricultural Experimental Station Paper No. 7038, Purdue University, West Lafayette, Indiana.

Bekele D, Alamirew T, Kebede A, Zeleke G, Melesse AM (2021) Modeling the impacts of land use and land cover dynamics on hydrological processes of the Keleta watershed, Ethiopia. Sustain Environ 7(1):1947632. https://doi.org/10.1080/27658511.2021. 1947632

Betrie GD, Mohamed YA, Van GA, Srinivasan R (2011) Sediment management modeling in the Blue Nile basin using SWAT model. Hydrol Earth Syst Sci 15:807-818

Bicknell BR, Imhoff JC, Donigian AS, Johanson RC (1997) Hydrological simulation program - FORTRAN (HSPF): User's manual for release 11. EPA-600/R-97/080. Athens, Ga.: U.S. Environmental Protection Agency.

Brath A, Montanari A, Moretti G (2006) Assessing the effect on flood frequency of land use change via hydrological simulation (with uncertainty). J Hydrol 324(1-4):141-153

Burnash RJC, Ferral RL, Mcguire RA (1973) A Generalized stream flow simulation system: Conceptual modal for digital computers, U. S. Dept. of commerce, National Weather Service and State of California, Department of Water Resources, Sacramento, California.

Chaplot V (2005) Impact of DEM mesh size and soil map scale on SWAT runoff, sediment, and NO3-N loads predictions. J Hydrol 312:207-222

Chaube UC, Suryavanshi S, Nurzaman L, Pandey A (2011) Synthesis of flow series of tributaries in Upper Betwa basin. Int J Environ Sci 1(7):59-75

Chawla I, Mujumdar PP (2015) Isolating the impacts of land use and climate change on streamflow. Hydrol Earth Syst Sci 19:3633-3651

Chiang LC, Liao CJ, Lu CM, Wang YC (2021) Applicability of modified SWAT model (SWAT-Twn) on simulation of watershed sediment yields under different land use/cover scenarios in Taiwan. Environ Monit Assess 193:520. https://doi.org/10. 1007/s10661-021-09283-9

Costa MH, Botta A, Cardille JA (2003) Effects of large-scale changes in land cover on the discharge of the Tocantins River, Southeastern Amazonia. J Hydrol 283:206-217

Crawford NH, Linsley RK (1966) Digital simulation in hydrology, Stanford Watershed Model IV. Technical Report- 39, Department of Civil Engineering, Stanford University, Stanford, CA.

Dong W, Cui B, Liu Z, Zhang K (2014) Relative effects of human activities and climate change on the river runoff in an arid basin in northwest China. Hydrol Process 28:4854-4864

El-Khoury A, Seidou O, Lapen DR, Que Z, Mohammadian M, Sunohara M, Bahram D (2015) Combined impacts of future climate and land use changes on discharge, nitrogen and phosphorus loads for a Canadian river basin. J Environ Manag 151:76-86

Ficklin DL, Luo Y, Luedeling E, Zhang M (2009) Climate change sensitivity assessment of a highly agricultural watershed using SWAT. J Hydrol 374:16-29

Getachew B, Manjunatha BR, Bhat HG (2021) Modeling projected impacts of climate and land use/land cover changes on hydrological responses in the Lake Tana Basin, upper Blue Nile River Basin, Ethiopia. J Hydrol 595:125974. https://doi.org/10. 1016/j.jhydrol.2021.125974

Günlü A, Kadığullar AI, Keleş S, Başkent EZ (2009) Spatiotemporal changes of landscape pattern in response to deforestation in Northeastern Turkey: a case study in Rize. Environ Monit Assess 148(1-4):127-137

Huang HJ, Cheng SJ, Wen JC, Lee JH (2008) Effect of growing watershed imperviousness on hydrograph parameters and peak discharge. Hydrol Process 22(13):2075-2085

Kamusoko C, Aniya M (2007) Land use/cover change and landscape fragmentation analysis in the Bindura District, Zimbabwe. Land Degrad Dev 18(2):221-233

Kim Y, Engel BA, Lim KJ, Larson V, Duncan B (2002) Runoff impacts of land-use change in Indian river Lagoon watershed. J Hydrol Eng 7(3):245-251

Kim J, Choi J, Choi C, Park S (2013) Impacts of changes in climate and land use/land cover under IPCC RCP scenarios on streamflow in the Hoeya River basin, Korea. Sci Total Environ 452-453:181-195

Kumar M, Denis DM, Sing SK, Szabó S, Suryavanshi S (2018) Landscape metrics for assessment of land cover change and fragmentation of a heterogeneous watershed. Remote Sens Appl Soc Environ 10:224-233

Laflen JM, Elliot WJ, Simanton JR, Holzhey S, Kohl KD (1991) WEPP soil erodibility experiments for rangeland and cropland soils. J Soil Water Conserv 46(1):39-44

Legates DR, McCabe GJ (1999) Evaluating the use of goodness-of-fit measures in hydrologic and hydroclimatic model validation. Water Resour Res 35(1):233-241

Li Z, Xu Z, Shao Q, Yang J (2009) Parameter estimation and uncertainty analysis of SWAT model in upper reaches of the Heihe river basin. Hydrol Process 23(19):2744-2753

Liang X, Lettenmaier DP, Wood EF, Burges SJ (1994) A simple hydrologically based model of land surface water and energy fluxes for GSMs. J Geophys Res 99(D7):14415-14428

Liu J, Chen JM, Cihlar J (2003) Mapping evapotranspiration based on remote sensing: an application to Canada's landmass. Water Resour Res 39:1189. https://doi.org/10.1029/2002WR001680

Lopes TR, Zolin CA, Mingoti R, Vendrusculo LG, de Almeida FT, de Souza AP, de Oliveira RF, Paulino J, Uliana EM (2021) Hydrological regime, water availability and land use/land cover change impact on the water balance in a large agriculture basin in the Southern Brazilian Amazon. J S Am Earth Sci 108:103224. https://doi.org/10.1016/j.jsames.2021.103224

Mehdi B, Lehner B, Gombault C (2015) Simulated impacts of climate change and agricultural land use change on surface water quality with and without adaptation management strategies. Agric Ecosyst Environ 213:47-60

Mekonnen DF, Duan Z, Rientjes T, Disse M (2018) Analysis of combined and isolated effects of land-use and land-cover changes and climate change on the upper Blue Nile River basin's streamflow. Hydrol Earth Syst Sci 22:6187-6207

Mishra AK, Ozger M, Singh VP (2009) Trend and persistence of precipitation under climate change scenarios for Kansabati basin, India. Hydrol Process 23:2345-2357

Mishra H, Denis DM, Suryavanshi S, Kumar M, Srivastava SK, Denis AF, Kumar R (2017) Hydrological simulation of a small ungauged agricultural watershed Semrakalwana of Northern India. Appl Water Sci 7:2803-2815

Moradkhani H, Baird RG, Wherry SA (2010) Assessment of climate change impact of floodplain and hydrologic ecotones. J Hydrol 395:264-278

Moriasi DN, Arnold JG, Van LMW, Bingner RL, Harmel RD, Veith TL (2007) Model evaluation guidelines for systematic 
quantification of accuracy in watershed simulations. Trans ASABE 50(3):885-900

Murty PS, Pandey A, Suryavanshi S (2014) Application of Semi distributed hydrological model for basin level water balance of the Ken basin of Central India. Hydrol Process 28(13):4119-4129

Nash JE, Sutcliffe JV (1970) River flow forecasting through conceptual models Part 1-A discussion of principals. J Hydrol 10(3):282-290

Neitsch SL, Arnold JG, Kiniry JR, Williams JR (2005) Soil and water assessment tool, theoretical documentation. Black Land Research and Extension Center, Texas Agricultural Experiment Station Texas

Nie W, Yuan Y, Kepner W, Nash MS, Jackson M, Erickson C (2011) Assessing impacts of land use and land cover changes on hydrology for the upper San Pedro watershed. J Hydrol 407:105-114

Niraula R, Meixner T, Norman LM (2015) Determining the importance of model calibration for forecasting absolute/relative changes in streamflow from LULC and climate changes. J Hydrol 522:439-451

Paudel S, Yuan F (2012) Assessing landscape changes and dynamics using patch analysis and GIS modeling. Int J Appl Earth Obs Geoinf 1(16):66-76

Paul M, Rajib MA, Ahiablame L (2017) Spatial and temporal evaluation of hydrological response to climate and land use change in three South Dakota watersheds. J Am Water Resour Assoc 53(1):69-88

Prowse TD, Beltaos S, Gardner JT, Gibson JJ, Granger RJ, Leconte R, Peters DL, Pietroniro A, Romolo LA, Toth B (2006) Climate change, flow regulation and land-use effects on the hydrology of the Peace-Athabasca-Slave system; findings from the northern rivers ecosystem initiative. Environ Monit Assess 113(1-3):167-197

Puno RCC, Puno GR, Talisay BAM (2019) Hydrologic responses of watershed assessment to land cover and climate change using soil and water assessment tool model. Glob J Environ Sci Manag 5(1):71-82

Rose S, Peters NE (2001) Effects of urbanization on streamflow in the Atlanta area (Georgia, USA) a comparative hydrological approach. Hydrol Process 15(8):1441-1457

Sahoo S, Dhar A, Debsarkar A, Kar A (2018) Impact of water demand on hydrological regime under climate and LULC change scenarios. Environ Earth Sci 77:341. https://doi.org/10.1007/ s12665-018-7531-2

Setegn SG, Srinivasan R, Dargahi B (2008) Hydrological modeling in lake Tana Basin, Ethopia, using SWAT model. Open Hydrol J 2:49-62

Sinha RK, Eldho TI, Ghosh S (2021) Assessing the impacts of land use/land cover and climate change on surface runoff of a humid tropical river basin in Western Ghats, India. Int J River Basin Manag. https://doi.org/10.1080/15715124.2020.1809434

Snija VS, Sherring A, Suryavanshi S (2018) Hydrological modeling of Amaravila watershed in Neyyar river basin using soil and water assessment tool. J Soil Water Conserv 17(3):259-266

Southworth J, Munroe D, Nagendra H (2004) Land cover change and landscape fragmentation-comparing the utility of continuous and discrete analyses for a western Honduras region. Agric Ecosyst Environ 101:185-205

Sridhar V, Nayak A (2010) Implications of climate driven variability and trends for the hydrologic assessment of the Reynolds Creek experimental watershed. J Hydrol 385:183-202

Srinivasan R, Arnold JG, Rosenthal W, Muttiah RS (1993) Hydrologic modeling of Texas Gulf Basin using GIS, In: Proceedings of $2^{\text {nd }}$ International GIS and Environmental Modeling, Breckinridge, Colorado, pp. 213-217.

Srinivasan R, Ramanarayanan TS, Arnold JG, Bednarz ST (1998) Large area hydrologic modeling and assessment part II: model application. J Am Water Resour Assoc 34(1):91-101
Srinivasan R, Zhang X, Arnold J (2010) SWAT unguaged: hydrological budget and crop yield prediction in the upper Mississipi river basin. Trans ASABE 53(5):1533-1546

Srivastava PK, Mehta A, Gupta M, Singh SK, Islam T (2014) Assessing impact of climate change on Mundra mangrove forest ecosystem, Gulf of Kutch, western coast of India: a synergistic evaluation using remote sensing. Theor Appl Climatol 120:685-700

Suryavanshi S, Pandey A, Chaube UC (2017) Hydrological simulation of the Betwa river basin (India) using the SWAT model. Hydrol Sci J 62(6):960-978

Teklay A, Dile YT, Asfaw DH, Bayabil HK, Sisay K (2021) Impacts of climate and land use change on hydrological response in Gumara watershed, Ethiopia. Ecohydrol Hydrobiol 21(2):315-332

Turner MG, Gardner RH, O'Neill RV (2001) Landscape ecology in theory and practice. Springer - Verlag, New York

Vitousek PM (1994) Beyond global warming: ecology and Global Change. Ecology 75(7):1861-1876

Wang GX, Zhang Y, Liu GM, Chen L (2006) Impact of land-use change on hydrological processes in the Maying river basin, China. Sci China Ser d: Earth Sci 49(10):1098-1110

Wang G, Yang H, Wang L, Xu Z, Xue B (2014a) Using the SWAT model to assess impacts of land use changes on runoff generation in headwaters. Hydrol Process 28(3): 1032-1042

Wang R, Kalin L, Kuang W, Tian H (2014b) Individual and combined effects of land use/cover and climate change on Wolf Bay watershed streamflow in southern Alabama. Hydrol Process 28:5530-5546

Williams JW, Izaurralde RC, Steglich EM (2008) Agricultural policy/ environmental extender model theoretical documentation, version 0604. Black Land Research and Extension Center, Texas, Joint Global Change Research Institute Pacific Northwest National Lab and University of Maryland

Willmot CJ (1981) On the validation of models. Phys Geogr 2(2):184-194

WMO (1966) Climatic change. WMO Technical Note 79, World Meteorological Organization, Geneva.

Wu K, Johnston CA (2007) Hydrologic response to climate variability in a great Lakes watershed: a case study with the SWAT model. J Hydrol 337:187-199

Xu ZX, Zhao FF, Li JY (2009) Response of stream flow to climate change in the headwater catchment of the Yellow River Basin. Quat Int 208(1-2):62-75

Yan R, Zhang X, Yanb S, Zhang J, Chen H (2018) Spatial patterns of hydrological responses to land use/cover change in a catchment on the Loess Plateau, China. Ecol Indic 92:151-160

Yang L, Feng Q, Yin Z, Wen X, Si J, Li C, Deo RC (2017) Identifying separate impacts of climate and land use/ cover change on hydrological processes in upper stream of Heihe River, Northwest China. Hydrol Process 31:1100-1112

Yin J, He F, Xiong YJ, Qiu GY (2017) Effects of land use/land cover and climate changes on surface runoff in a semi-humid and semiarid transition zone in northwest China. Hydrol Earth Syst Sci 21:183-196

Young RA, Onstad CA, Bosch DD, Singh VP (1995) AGNPS: An agricultural nonpoint source model. Int workshop on Computer applications in Water Management p. 33.

Yu Y, Liu J, Yang Z, Cao Y, Chang J, Mei C (2018) Effect of climate change on water resources in the Yuanshui River Basin: a SWAT model assessment. Arab J Geosci 11:270. https://doi.org/10.1007/ s12517-018-3619-y

Yuan F, Sawaya KE, Loeffelholz BC, Bauer ME (2005) Land cover classification and change analysis of the Twin Cities (Minnesota) Metropolitan Area by multitemporal Landsat remote sensing. Remote Sens Environ 98:317-328 
Zhang C, Shoemaker CA, Woodbury JD, Cao M, Zhu X (2013) Impact of human activities on stream flow in the Biliu River basin, China. Hydrol Process 27:2509-2523

Zhang L, Nan Z, Xu Y, Li S (2016) Hydrological impacts of land use change and climate variability in the headwater region of the Heihe river basin, Northwest China. PLoS ONE 11(6):e0158394

Zhang L, Karthikeyan R, Bai Z, Srinivasan R (2018) Analysis of streamflow responses to climate variability and land use change in the Loess Plateau region of China. CATENA 154:1-11
Publisher's Note Springer Nature remains neutral with regard to jurisdictional claims in published maps and institutional affiliations. 